\title{
Старообрядческая книжность и старообрядческие книжники XX-XXI в.: на материале частных библиотек
}

\begin{abstract}
Аннотачия. Статья посвящена старообрядческой книжности - одной из ключевых тем в историографии старообрядиества (работы Н. Ю. Бубнова, Н. С. Гурьяновой, И. В. Поздеевой, Н. Н. Покровского и др.). Но несмотря на заявляемъий авторами комплексный подход, изучение книжных памятников и судеб носителей традииии нередко велось отдельно. Благодаря «соииальной археографии» (подходу, сформулированному О. Н. Бахтиной и E. Е. Дутчак), указанная тема входит на новый уровенъ, и изучение книжности в контексте сочиальной среды ее бытования стало реальностью, а не только декларачией. Автор обратился к памятникам старопечатной кириллицы. Основу исследования составили опубликованные каталоги, а также полевые дневники экспедииий 1970-2010-х г2. в Верхокамъе и Южную Вятку. Их данные были подвергнуты как количественным, так и описательным методам анализа. В результате удалось проследить судъбы старообрлдческих книжников, истории как отдельных книжных памятников, так и иелых комплексов, наглядно показать прочесс постепенного вытеснения старопечатных книг более новыми изданиями. Последний, по мнению автора, связан не столько с упадком книжности, сколько с адаптачией местных старообрядческих общин к современным реалиям.
\end{abstract}

Ключевые слова: археография, итение, старообрядчество, старообрядческая книжность, издания старопечатной кирилличы, экспедичия, Верхокамъе, Южная Вятка, полевые исследования, традииия.

Abstract. The article is focused on Old Ritualist booklore - one of the key topics in the historiography of Old Ritualism (the works of N. Y. Bubnor, N. S. Guryanov, I. V. Pozdeev, N. N. Pokrorsky and others). But despite these authors' stated complex approaches, the study of the Old Ritualists' book monuments and the destinies of the carriers of this tradition was often examined separately. Through "social archaeography" (an approach developed by O. N. Bakhtin and E. E. Dutchak), the named topic is brought to a new research level and the study of booklore in the context of the social sphere of its existence became a reality and not just a declaration. The author used works in old printed Cyrillic. The basis of this study consists of published catalogues, as well as field diaries from the expeditions in 1970-2010s to Verhkamye and South Vyatka. The derived information was subjected to quantitative and also descriptive methods of analysis. As a result, the author was able to trace the destinies of Old Ritualistic scribes, the history of particular book monuments, as well as whole bodies of writings, and to clearly demonstrate the process of the gradual displacement of old-typed book forms with newer editions. The last, according to the author, is related not so much to the fall of traditional booklore, as much as to the adaptation of local Old Ritualist communities to modern realities.

Key words: archaeography, reading, Old Ritualists, Old Ritualist booklore, Old Cyrillic publication, expedition, Verhokamye, South Vyatka, field studies, tradition.

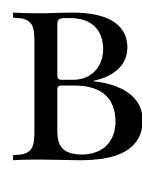

2006 г. на конференции «Традиционная книга и культура позднего русского средневековья» [27] развернулась полемика вокруг задач и методов археографии и понятия термина «социальная археография». Предлагаемый О.Н. Бахтиной и Е.Е. Дутчак подход апеллировал к необходимости максимально четкого изучения не только старообрядческого социума или памятников старообрядческой книжности, но и «самого процесса взаимодействия человека и книги / конфессионального текста» [6]. Эту же идею, но в более категоричной форме, отстаивал В.В. Керов [12]. И.В. Поздеева выступила с резкой критикой самого термина «социальная археография», выдвинутого Бахтиной, Дутчак и Керовым. Суть ее аргументации сводилась к тому, что археография изначально «социальна», что археография еще в 1970-х-1980-х гг. «ставила вопросы о синхронном составе и диахронной истории 
Историография и источниковедение

DOI: $10.7256 / 2222-1972.2016 .5 .20012$

местной книжности» [21]. К сожалению, она увидела в работах трех авторов просто теоретический призыв, но не реальную попътку введения в научный оборот и анализа даннъх о бытовании памятников (и целых их комплексов) в той или иной социальной среде. А ведь необходимость именно такого подхода в исследованиях о старообрядчестве на конференции была затронута и в докладе А.А. Пригарина [26]. В заключение своей рецензии на доклады Бахтиной, Дутчак и Керова Поздеева резюмировала: «хоть социальной назови, а археографическую работу сделай» - и высказала надежду, что «в ближайшие годы мы сможем познакомиться с результатами реального осуществления авторами соответствующих полевых исследований» [21. С. 319].

Впрочем, результаты не замедлили себя ждать. Вскоре после дискуссии и перед выходом сборника статей по итогам конференции увидела свет книга Е.Е. Дутчак, в которой предлагаемые подходы нашли отражение [8]. На конференции 2009 г. О.Н. Бахтина и Е.Е. Дутчак продемонстрировали новые примеры результативности этих подходов, правда, без упора на определение «социальная археография» [5, 10]. Следует сказать, что на той же конференции был прочитан доклад (а затем была опубликована статья) сотрудницы Межкафедральной археографической лаборатории Е.В. Градобойновой [7], во многом также опирающийся на подход О.Н. Бахтиной и Е.Е. Дутчак. Попыткой анализа среды бытования региональной старообрядческой книжности в контексте фольклорных и историко-конфессиональных традиций той или иной местности стали недавние работы коллектива московских археографов [15, 16]. Следует отметить, что Е.Е. Дутчак увидела близость отстаиваемых ей подходов, и тех, что нашли отражение в данных сборников [9]. Указанные публикации, данные полевых дневников, и материалы каталогов старопечатной кириллицы, выпущенные под эгидой археографов Московского университета, стали основой предлагаемой статьи. Ее целью следует считать еще одну попытку продемонстрировать возможности социально-археографического подхода, под которым автор понимает максимально полный учет данных о синхронном составе и диахронной истории местной книжности в контексте судеб носителей традиции. Данные вопросы будут рассмотрены на материале двух регионов: Южной Вятки и Верхокамья. При этом в статье будет идти речь именно об изданиях старопечатной кириллицы, которые являются основой чтения и богослужения староверов, а не полемические сочинения. Анализ последних -тема отдельного исследования.

В августе 2010 г. отряд археографической экспедиции МГУ имени М.В. Ломоносова оказался в п. Донаурово Уржумского р-на Кировской обл. - ранее крупном центре староверия. Здесь уживались представители поморского, федосеевского и филипповского согласий. Последнее оказалось еще в XIX в. разделено на «шихалей» («ионовцев») и на «максинерцев» («васинцев»). Поскольку речь идёт о беспоповских старообрядческих согласий, то местные общины делятся на «братских» и «не братских». Членами «братии» считаются дети и подростки, а также несемейные и престарелые, способные подчиняться жестким требованиям иноческого жития в миру. Они образуют своего рода «монастырь». Именно на членов братии, как наиболее грамотных, распространяется вся строгая система запретов: На Верхокамье термину «братия» соответствует «собор».

Сейчас жители этих наполовину обезлюдевших мест не так держатся за старую веру. Но, тем не менее, край этот до сих пор полон неожиданных открытий. То проскользнет в беседе какой-либо интересный фольклорный сюжет, то у кого-то дома выявятся старые листочки, не представляющие никакой материальной, да в общем-то и исторической (кроме как для профессиональных исследователей) ценности, однако содержащие любопытные сведения по так называемой локальной истории (local history).

Археографы МГУ познакомились с членом шихалёвской братии И.Я. Ч-вым (1958 г.р.). Он сам был удивлен визитом к нему: мол, еще молод, надо со стариками говорить... Но в то же время у него самого были некоторые вопросы, на которые он не мог получить ответ у стариков: либо их неудобно спрашивать, либо те и вовсе не знают. А вот посторонним людям, каковыми были мы, эти вопросы задать можно. Его в первую очередь интересовали проблемы местного раскола: как же это люди, молящиеся по одним правилам и придерживающиеся одинаковых обрядов, оказываются «разноверами». И как другие филипповцы (да и не только они) кладут икону на покойника: лицом к покойнику или «затылком» к нему? Ведь именно из-за этого и разделились в свое время максинерцы с шихалями $[16,28]$. В конце концов, беседа продолжилась в доме. Хозяин показал свою небольшую комнату 


\section{Исторический журнал: научные исследования № 5 (35) • 2016}

DOI: 10.7256/2222-1972.2016.5.20012

(он, как член братии, то есть посвятивший себя молитве, «отделился» от жены и дочери). Все в этой комнате выдает характер хозяина. Божница с иконами, аккуратно, по-военному, заправленная кровать, небольшой стол с двумя стульями, полка с книгами. А на полке стоят Псалтырь XVII в. (точнее без справочников определить было нельзя), Апостол, изданный на Московском печатном дворе в 1648 г., разного рода старообрядческие газеты и... двухтомник В.С. Высоцкого [4. С. 33]. «Есть в нем нечто» - сказал И.Я. Ч-в, заметив, что мы обратили внимание на эту книгу.

Затем мы еще были у этого респондента в 2011, 2012 и 2015 гг., он каждый год показывал нам свои «приобретения». Относительно молодой, пытливый, он у всех членов братии снискал искреннее уважение. Вот старики и стали передавать ему семейные раритеты. Ведь грех, когда книга без дела лежит, - ее читать надо. Он читает и не просто читает, а размышляет. Определение некоторых книг оказалось делом сложным. В частности, у нашего благодетеля (именно так по старинной археографической традиции мы называем всех, кто открыл какие-то новые страницы в истории староверия, или просто когдалибо нам помог) оказался «Стоглав». Причем этот памятник XVI в. был переписан в XVIII в. в Поморье насельниками знаменитой старообрядческой Выговской пустыни (об говорят характерные заставки, палеография) на бумаге фабрики Афанасия Гончарова. Каким-то образом этот памятник оказался на Вятке. Так одна рукопись связала Московский Кремль, где в 1551 г. были утверждены постановления Стоглавого собора, с Поморьем XVIII в. и с Вяткой $\mathrm{XX}$-XXI вв., а если говорить о личностях, участвовавших в этом процессе, то это и царь Иван Грозный, и А. Гончаров, дед жены А.С. Пушкина, и наш благодетель И.Ч-в и сотни других лиц (начиная от переписчиков Выговской пустыни, кончая вятскими владельцами).

Вопрос миграции книжных памятников и попадания их в тот или иной регион - один из ключевых. В частности, по записям на рукописях, выявленных в другом старообрядческом регионе - Верхокамье, - И.В. Поздеева показала, что большинство их имело изначально бытование в Центральной России, а затем они оказались на Урале. При этом в коллекции мало книг, изначально бытовавших в Сибири. Этот факт наглядно показывает направление миграции книг, совпадающий с вектором расселения самих старообрядцев [20]. В настоящее время наблюдения этой статьи могут быть заметно конкретизированы.

Во все времена были люди, целенаправленно занимавшиеся распространением книг, в первую очередь старопечатных, так как именно они стали основой старообрядческой культуры. Известно, что в Верхокамье бывал видный деятель московского староверия Ф. Румянцев (ок. 1905-1930-е гг.(?), расстрелян). Он три раза приезжал в Верхокамье, писал сюда письма, призывал христиан «щепотью не молиться» [1. С. 15], в старообрядческих библиотеках хранились «беседы Румянцева» [17]. Кроме того, он же и снабжал местных поморцев книгами (в первую очередь, стиховниками). Известно также, что книжная торговля была широко распространена и в с. Кулига. Именно здесь на рубеже XIX-XX вв. торговал уставщик Антон Филиппович, ездивший за старинными книгами в Москву [2. С. 52]. Видимо, постоянные контакты с Москвой, выраженные, в частности, в купле-продаже книг, значительно способствовали тому, что Верхокамье превратилось в выдающийся центр старообрядческой культуры. На Южной Вятке также были свои библиофилы. Одна респондентка (П-ва 3., 1931 г.р, филипповка-шихалёвка, бывшая духовная мать) рассказывала, что у ее отца был постоянный поставщик-продавец в Нолинском уезде [3. с. 30]. (Выдающийся издатель и коллекционер Л. А. Гребнев (1867-1932) также был постоянно связан с Москвой и др. центрами, а его богатейшее собрание было высоко оценено исследователями. Археографам МГУ удалось выявить книги, принадлежавшие семье Гребневых [16, с. 171].)

Так или иначе, старообрядческие библиотеки никогда не были (и тем более не являются сейчас) явлением стабильным. Они не только пополнялись, но и разделялись между наследниками, изымались властями, покидали регион и т.д. В частности, выявленные археографами в 2010 г. рукописи и книги д. Савиново сейчас находятся вне региона: их забрала одна из дочерей последней хранительницы и перевезла в Москву. Благодаря оцифрованным копиям они не потеряны для науки, а отдельные памятники даже опубликованы, например «Рукопись Иоанна», текст который представляет сочинения рубежа XVIII-XIX вв. [16. с. 173].

Все это нашло отражение в полевых дневниках экспедиций, при фиксации рассказов носителей традиции о собраниях своих роди- 


\section{Историография и источниковедение}

DOI: $10.7256 / 2222-1972.2016 .5 .20012$

телей, дедов и бабушек, а так же соборных библиотеках. В библиотеке И.Я. Ч-ва в 2012 г. появилась «Книга о вере» (М.: Единоверческия типография, 1887) со следующей записью на 1-м припереплетном листе (привожу в современной орфографии): «По разделу братьев / Какия книги принадлежат мне / Зоту Васильевичу Чернышову / 1я Кормча[я] 2 Охтай 3 Номоканон / 4 Пролог мартовский 5 Вера / 7я Минея 8 Никон Черная горы / 9я Свещенноинок 10 Часовник / 11 Макарьево видение 12 церковное око, / 13 Псалтырь маленна / 14 Следовательна псалтырь». Автор записи Зот Васильевич Чернышов -один из ключевых деятелей местного староверия рубежа XIX -XX вв.; стоял у истоков сложения шихалёвского согласия. К 2015 г. в библиотеке того же И.Я. Ч-ва появилась книга «Шестоднев» (М.: Единоверческая типография, 1884), в начале XX в. принадлежавшая Алексею Васильевичу Чернышову, брату Зота. Внук Зота Чернышова, сын удочеренной племянницы, Н.И. Ч-в (1924 - 2016), проживал в соседнем населенном пункте и на молениях часто общался с И.Я. Ч-вым. Однако он не подозревал о существовании этих книг. То, что носители традиции могут и не подозревать о наличии тех или иных книг в библиотеке братии/соборе, а также в домашних собраниях своих единоверцев, - одна из слабых сторон старообрядческих библиотек. Наличие каталогов, наподобие того, что опубликован И.В. Ровинской [17], - скорее исключение, чем правило.

Интересные выводы удается сделать при анализе фактов поступления в архивохранилища памятников книжности. Здесь можно обратиться к базе данных «Записи на книгах старопечатной кириллицы», которую автор составляет с 2008 г. Основу ее составили каталоги старопечатной книжности, подготовленные под эгидой археографической лаборатории. Безусловно, основная ценность для историков - сами записи на книгах, однако даже такие сведения, как время и источник поступления книги в архивохранилище, могут наглядно показать трансформационные процессы в книжной культуре старообрядчества второй половины XX-XXI вв.

Археография всегда уделяла пристальное внимание социальной стороне судеб книжных памятников. Однако сейчас, к сожалению, это, пожалуй, отличительная черта именно московской университетской археографии. Так, все памятники, собранные экспедициями МГУ, имеют подробные сведения о времени, месте находки, а также информацию о последнем владельце: его имя, принадлежность к тому или иному согласию, а иногда - и о статусе в общине. Информация, например, о памятниках, собранных ярославскими археографами, значительно менее подробна. Далеко не всегда известен даже год находки. Всего в базе данных учтено 4428 экземпляров 1177 изданий 79 типографии 33 городов. В настоящее время в базе данных фигурируют 870 экз. (то есть более $10 \%$ ), полученных в ходе археографических экспедиций 1960-2000-х гг. (273 получены в 1960-е гг., 270 - в 1970-е гг., 280 в 1980-е гг., 46 в 1990-е и 2010-е гг. вместе). Это не окончательные цифры: они выявлены на основе только четырех каталогов $[13,14,23,24]$. Однако они показывают определенные процессы в книжной культуре русского старообрядчества. В 1960-е и 1970-е гг., когда традиционная культура в ряде регионов представляла собой стройную систему, книжные находки носили массовый характер. С уходом поколения, воспитанного до революции, оскудевать стала и книжная культура.

Интерес представляет репертуар книжных памятников, в 1960-2000-х гг. перешедших в хранилища страны. В 2001 г. Поздеева выделила следующие типы изданий: литургические (пригодные как для богослужения, так и для обучения), учительные и чительные (книги, предназначенные непосредственно для чтения и самостоятельного осмысления верующими в отличии от богослужебной, то есть литургической литературы) [25. с. 13-26]. В 2007 г. ей предложена несколько иная классификация: Писание, издания для обучения, богослужения, учительные и справочнъе [22. с. 126-127]. Выделение текстов Писания как самостоятельного типа изданий вполне оправдано, поскольку, например, Псалтырь выполняла функции не только богослужебной, но и учительной книги; Евангелие является не только чительной книгой, но и богослужебной. В свою очередь разделять учительные книги и книги для обучения представляется излишним, тем более что обучение грамоте и основам веры шло одновременно, а книг собственно для обучения было издано относительно немного. Можно разделить и разные типы изданий Псалтыри. Сама по себе Псалтырь - неотъемлемая часть Писания; Псалтырь учебная -пример учебной книги, Псалтырь с восследованием - богослужебной. При всей условности подобного рода классификаций (в первую очередь, в силу невозможности разделить функции того или иного вида издания) можно выделить четыре типа изданий: 


\section{Исторический журнал: научные исследования № 5 (35) • 2016}

DOI: $10.7256 / 2222-1972.2016 .5 .20012$

- Писание (издания Библии и отдельных её разделов; тексты выполняют двойную функцию: они могут использоваться как в богослужении, так и в индивидуальном духовном поиске),

- литургические (предназначены для богослужения.),

- чительные (предназначены непосредственно для чтения и самостоятельного осмысления),

- учебные.

Первое, что бросается в глаза, это достаточно равномерное распределение находок 1960-2000-х гг. по типам книг. Их можно представить в виде следующей таблицы:

Таблииа

\begin{tabular}{|l|c|c|c|c|c|}
\hline \multicolumn{1}{|c|}{ Книги } & $\mathbf{1 9 6 0 - е ~ г г . ~}$ & $\mathbf{1 9 7 0 - е ~ г г . ~}$ & $\mathbf{1 9 8 0 - е ~ г г . ~}$ & $\begin{array}{c}\mathbf{1 9 9 0 - е ~ и ~} \\
\text { 2010-е гг. }\end{array}$ & Итого \\
\hline $\begin{array}{l}\text { Литурги- } \\
\text { ческие }\end{array}$ & $\begin{array}{c}195 \\
(71 \%)\end{array}$ & $\begin{array}{c}162 \\
(60 \%)\end{array}$ & $\begin{array}{c}166 \\
60 \%)\end{array}$ & $33(72 \%)$ & \\
\hline Писание & $51(19 \%)$ & $84(31 \%)$ & $51(18 \%)$ & $4(9 \%)$ & \\
\hline $\begin{array}{l}\text { читель- } \\
\text { ные }\end{array}$ & $21(8 \%)$ & $10(4 \%)$ & $52(18 \%)$ & $9(19 \%)$ & \\
\hline Учебные & $6(2 \%)$ & $14(5 \%)$ & $12(4 \%)$ & - & \\
\hline Итого & 273 & 270 & 281 & 46 & 870 \\
\hline
\end{tabular}

Безусловно, сбор памятников книжности в разное время подчинялся разным задачам. По свидетельству участников археографических экспедиций Московского университета, в 1960-е гг. и начале 1970-х гг. «брали все, что давали». Во второй половине 1970-х гг. уже встал вопрос избыточного количества одинаковых изданий. Тогда было решено брать не более двух экземпляров изданий, учтенных в книге А.С. Зёрновой [11], и то - только при наличии записей. Кроме того, сбору подлежали книги с уникальными записями (например, царские вклады). То есть в какой-то степени выявленные результаты «рукотворны», однако не следует забывать и позиции самих носителей традиции: с чем они готовы были расстаться, а с чем нет. Кроме того, в базе данных учтены результаты деятельности не только Московского университета. В частности, археографическими изысканиями активно занимались организации Ярославского края. Пик активности их приходится на 1980-е гг., то есть то время, когда изыскания МГУ стали идти «на спад». В это время ярославцы тоже «брали все, что давали». Таким образом, исходя из того, что в базе данных учтены работы разных археографических центров (цели и задачи которых в разное время могли не совпадать), а также из означенной позиции самих староверов, некоторые выводы относи- тельно статистики типов и видов получаемых книжных памятников сделать можно.

Во все годы археографические экспедиции привозили больше всего памятников литургической книжности (60\%-72\%). На втором месте по числу находок следуют экземпляры разных изданий Писания (9\%-24\%). Затем по числу находок идут чительные книги (4\%-19\%) и, наконец, учебные книги (2\%-5\%). Лишь один раз (в 1990-е и 2010-е гг.) количество чительных книг превышает тексты Писания. Такое распределение вполне понятно, поскольку именно литургические книги составляли основу издательской деятельности типографий. Что касается учебных изданий, то картина здесь не вполне показательна, так как они сильно зачитывались и плохо сохранились до наших дней [22. с. 62].

В 1960-е гг. было получено 273 экземпляра 31 вида книг. Для того, чтобы легче ориентироваться в них в конце статьи приведен небольшой словарь (см. Приложение). На первом месте по числу находок оказались Минеи (57 служебных, 12 праздничных и 11 общих с праздничной); на втором месте -Триоди (15 постных и 11 цветных), на третьем - Октоих (24). Все это памятники литургической литературы. Затем идут Апостол (18), Евангелия (16), Требники (15), на третьем Псалтыри (13), Служебники и Прологи (по 10) -т.е. и тексты Писания, и литургические книги. В 1970-е гг. разнообразие стало немного меньшим. Всего было собрано 270 экземпляров 26 видов книг. На первом месте, по прежнем разного рода Минеи - 61 (31 служебная, 13 праздничных, 9 общих и 8 общих с праздничной), но затем идут тексты Писания: Апостолы (34), Псалтыри (24), Евангелия (20). Затем снова литургические книги: Триоди (по 16 постных и цветных), Октоих (15).

Наконец, 1980-е гг, ставшие апогеем археографических находок (связано это, в первую очередь с появлением новых исследовательских центров; например в Ростово-Ярославском регионе экспедиции проводили Ярославский государственный университет и Ярославская областная библиотека), также существенно пополнили отечественные хранилища. В базе данных учтено 281 поступление этого периода, представляющие 33 вида книг. На первом месте, по-прежнему, Минеи (29 служебных, 14 общих с праздничной, 10 праздничных и 8 общих), затем Триоди (18 цветных и 12 постных), однако на третьем месте - Псалтырь (21), которая, как известно, являясь частью Писания и основной чи- 
тельной (а в старину ещё и учительной) книгой, затем Апостол (18), Прологи (16).

За 1990-2010-е гг., когда поток книг «иссяк» (это связано как с общим уменьшением книг в традиционной среде бытования, так и с ослаблением самой традиции), учтено 46 книг 22 видов. На первом месте, по-прежнему, Минеи (по 4 общих и служебных, 3 общих с праздничными), но на втором -Псалтырь с восследованием (7 находок). И это при том, что в 1960-е она была лишь на 11 месте (7 находок), 1970-е гг. 13 (9 находок), а в 1980-е гг. -на 6 (14 находок). Известно, что именно Псалтырь с восследованием во второй половине ХХ в. стала основой старообрядческого (в первую очередь беспоповского) богослужения.

Таким образом, мы видим, что в 1960-е и 1970-е гг. старообрядческие общины достаточно легко расставались с богослужебными книгами, сохраняя в своих библиотеках тексты Писания и книги чительные. В данный период вера, значительно потеряв свои позиции в качестве формы коллективной памяти, оставалась ещё формой индивидуальной идентификации. К слову сказать, именно в этот период начинается процесс упрощения богослужебной практики. В частности, она все больше и больше ведется по одной книге - Псалтыри следованной. Когда же очередь дошла до чительных книг, можно говорить о кризисе старообрядческой традиции в целом. То, что сейчас старообрядцы готовы расставаться даже с Псалтырью следованной, свидетельствует о крайней степени затухания традиции.

Состав старообрядческих библиотек, безусловно, сильно изменился за вторую половину $\mathrm{XX}$ в. Однако нельзя сказать, что археографические находки стали своего рода «безвозвратными потерями» для носителей традиции. Место книг, представлявших интерес для исследователей, заняли менее ценные издания. В первую очередь ими стали более поздние перепечатки.

До второй половины XX в. основой старообрядческой культуры была дониконовская книга, т.е. издания, выпущенные до церковной реформы 1650-х гг. В настоящее время наличие дониконовских изданий в домашних библиотеках старообрядцев -редкость. Носители традиции стараются соблюдать правило: мол, новые книги допустимы для чтения, но богослужение ведется только по дониконовским. В результате из более чем 170 печатных книг, выявленных в настоящее время у староверов Южной Вятки, лишь 15 были изданы в XVI-XVII вв. [16. с. 161164]. Более того, даже соборная библиотека одной из общин (поморцев или, как они здесь себя называют, «даниловцев») Южной Вятки, по книгам которой ведутся моления, целиком состоит из перепечаток конца XIX-начала XX вв. [18. с. 12-13], по которым, в том числе, ведется богослужение! И самих членов братии это не смущает, а некоторые и вовсе не знают о позднем происхождении книг.

Примечателен один эпизод, произошедший в археографической экспедиции 2011 г. Участники экспедиции пришли к сыну одной умершей староверки. Тот сказал, что мать благословила внучку псалтырью. Естественно, перед глазами начинающих исследователей уже рисовалось издание XVII в. На наводящий вопрос, какой величины было издание, был получен интригующий ответ: «Маленькая, в карман положить можно» (то есть, нечто вроде $\left.16^{0}\right)$. Понятно, что таких изданий в XVII в. не было и перед археографами замаячила перспектива нахождения неизвестного издания: ведь в то время издания были в $2^{0}, 4^{0}, 8^{0}$. Но на поверку книга оказалась «безвозмездным даром от Гедеоновых братьев» [4. с. 19-20], то есть имела протестантское происхождение. Кстати, в Уржуме имеется довольно крупная община баптистов.

T.е. для современных староверов важна не столько сама книга (как памятник старины, наследие предков), а её содержание, которое может быть воспроизведено и в более поздних изданиях. В этом плане примечательно, что любимым чтением одной представительницы шихалёвской братии в последние годы жизни (т.е. в 1990-е гг.) был ксерокс (!) с издания духовных стихов, который был предоставлен ей, видимо, сотрудниками БАН.

Судьба книжных памятников, находящихся в настоящее время у староверов, имеет два варианта. Первый: они оказываются в руках мошенников, обманом изымающих их из среды бытования, или ученых, которые, пополняя государственные архивохранилища, также изымают памятники из среды бытования. Второй вариант: они оказываются в руках местных книжников, типа И.Я. Ч-ва, с рассказа о котором и началась данная статья. Во втором случае уникальные памятники остаются в регионе, но уже не являются основой библиотеки носителя традиции, а составляют лишь более или менее значимый её сегмент. Они могут сто- 


\section{Исторический журнал: научные исследования № 5 (35) • 2016}

DOI: 10.7256/2222-1972.2016.5.20012

ять на одной полке как с более новыми изданиями духовного характера, так и со светскими. Вспомним двухтомник В.С. Высоцкого на одной полке с дониконовскими Апостолом и Псалтырью. Кстати, у упомянутой 3.К. П-вой (1931 г.р.) на полке среди других книг стоит и книга Гече «Библейские истории» (М.: Политиздат, 1988) [19. с. 29].

Анализ бытования памятников старопечатной кириллицы позволяет сделать следующие выводы. Ракурс исследования самого процесса взаимодействия человека и книги/текста имеет широчайшие перспективы, причем как для собраний, находящихся ныне в официальных архивохранилищах, так и «живых». Книжность невозможно представить без судеб создателей и хранителей конкретных памятников, их родственного и конфессионального окружения. Для дальнейшего изучения взаимодействия читателя и книги необходим анализ восприятия текста (т.е. изучение внутренних аспектов истории книжной культуры). В этой области есть значительные достижения. В частности анализ размышлений над текстом, прочитанным разными поколениями соборных, показан в работах Е.Б. Смилянской. Пример чтения «нарассуд» приведен мной и в сборнике, посвященном старообрядчеству Верхокамья [15 c. 197-202]. Однако это большая проблема требует проведения отдельных полевых исследований с широкой программой опроса. Кроме того, важным источником знаний о восприятии текста являются многочисленные пометы на полях, которые оставляли поколения владельцев, читателей, хранителей и т.д. книг. Однако и эта работа - пока дело будущего.

Завершая статью, отметим следующие. В литературе давно подмечено: изначально для старообрядцев «книга не вещь, она подобна иконе и является духовным окормителем и руководителем в деле спасения» [5. С. 670]. Со второй половины XX в. «старая книга» все больше и больше воспринимается как «одна из многих книг». Это приводило к тому, что: и другие книги читать можно, и в расставании со старыми особого греха нет. Включение в круг чтения иноконфессиональных текстов и «отдача» старых книг, издавна бытовавших в рамках данной конфессии (последнее во многом ускорено археографическими работами, ведшихся с 1960-х гг.) совпали по времени. Сперва, носители традиции относительно легко расставались с богослужебными книгами, а затем уже и с книгами, предназначенными для индивидуального осмысления. Впрочем, подмеченные процессы не следует однозначно считать проявлением упадка старообрядчества в частности и традиционной культуры в целом. Скорее можно говорить о них как механизмах адаптаиии традиционной культуры вызовам сегодняшнего дня. Полученные выводы следует считать показателем әффективности «социальной археографии».

\section{Приложение: Названия книг}

Апостол - часть Библии, включающая Деяния, Послания апостолов и Апокалипсис.

Минеи - богослужебные книги (Минеи служебные или месячные) и книги для чтения (Минеи четьи), содержащие жития святых, сказания о церковных праздниках и поучения. В служебных Минеях службы святых приведены для каждого дня года (обычно по числу месяцев разделяются на 12 томов).

Октоих (Октай, Охтай, Осьмогласник) - богослужебная книга, содержащая чинопоследования вечерни, повечерия, утрени и Литургии для шести будничных дней недели, а для воскресных дней - ещё и малой вечерни и полунощницы. Песнопения по способу пения разделяются на восемь гласов (отсюда название книги) или напевов, из которых каждый употребляется в продолжение одной седмицы.

Пролог - свод сокращенных житий святых (краткая редакция Миней четий), поучительных слов Василия Великого, Иоанна Златоуста и др., в котором тексты расположены по дням года; издается в четырёх трёхмесячных томах (по числу времён года).

Псалтырь с восследованием содержит псалтирь, разделенную на двадцать кафизм с указанием тропарей и молитв, читаемых после них, а также часослов и месяцеслов, что позволяет использовать её в богослужении.

Служебник - богослужебная книга, содержащая последования чинов Литургии Василия Великого, Иоанна Златоуста и Преждеосвященных Даров.

Требник (Потребник) - богослужебная книга, содержащая чинопоследования Таинств и других священнодействий, совершаемых православной церковью в особых случаях и не входящих в состав храмового (общественного) богослужения суточного, седмичного и годового круга. Получила своё название от слова «треба» 


\section{Историография и источниковедение}

(«жертва», «жертвоприношение», «молитва», «исполнение священного обряда»).

Триодь (Триодион) - богослужебная книга, содержит трёхпесенные каноны (трипеснцы), откуда и происходит название. Выделяют Триодь постную (включает молитвословия на дни

\section{Библиография:}

1. Архив Межкафедральной археографической лаборатории (далее АМАЛ). Ф. Верхокамье. Дневник М.: Леренман, 1974.

2. АМАЛ. Ф. Верхокамье. Дневник Е. Смилянской, 1975.

3. АМАЛ. Ф. Южная Вятка. Дневник В. Богданова, 2011.

4. АМАЛ. Ф. Южная Вятка. Дневник В. Богданова, К. Буйновой, 2010.

5. Бахтина О.Н. Кириллическая книга: современные аспекты восприятия и изучения // Язык, книга и традиционная культура позднего русского средневековья в жизни своего времени, в науке, музейной и библиотечной работе XXI в. М.: Изд-во МГУ, 2011. С. 666-674.

6. Бахтина О.Н., Дутчак Е.Е. От "книги читаемой" к "человеку читающему": из опыта работы археографической экспедиции Томского университета (1986-2006) // Традиционная книга и культура позднего русского средневековья. В 2 ч. Ч. 2. Ярославль: Ремдер, 2008. С. 285-300.

7. Градобойнова Е.В. Роль кириллических печатных изданий в формировании мировоззрения старообрядцев-беспоповцев // Язык, книга и традиционная культура позднего русского средневековья в жизни своего времени, в науке, музейной и библиотечной работе XXI в. М.: Изд-во МГУ, 2011. С. 610-624.

8. Дутчак Е.Е. Из "Вавилона" в "Беловодье": адаптационные возможности таежных общин староверов-странников (вторая половина XIX в. - начало XXI в.). Томск: Изд-во Том. ун-та, 2007. 414 C.

9. Дутчак Е.Е. Полевая археография вчера, сегодня и завтра: размышления о новых публикациях Московского университета // Вестник Томского государственного университета. 2015. № 396. С. 85-90.

10. Дутчак Е.Е. Старообрядческая книга: "болевые точки" научного опознания поздней кириллической рукописи // Язык, книга и традиционная культура позднего русского средневековья в жизни своего времени, в науке, музейной и библиотечной работе XXI в. М.: МГУ, 2011. С. 674-689.

11. Зёрнова А.С. Книги кирилловской печати, изданные в Москве в XVI-XVII вв. М.: ГБЛ, 1958.152 с.

12. Керов В.В. Об археографии: классической и социальной // Традиционная книга и культура позднего русского средневековья. В 2 ч. Ч. 2. Ярославль: Ремдер. 2008. С. 300-312.

13. Кириллические издания XVI-XVII вв. в хранилищах Пермской области. Пермь, 2003. 488 с.

14. Кириллические издания Ростово-Ярославской земли (1493-1652 гг). Ярославль - Ростов, 2004. 630 с.

15. Материалы к истории старообрядчества Верхокамья: по итогам комплексных археографических экспедиций исторического факультета МГУ имени М.В. Ломоносова: сборник документов, М.: МАКС Пресс, 2013. 276 с.

16. Материалы к истории старообрядчества Южной Вятки (по итогам комплексных археографических экспедиций МгУ имени М.В. Ломоносова). М.: МАКС Пресс, 2012. 306 с.

17. Описание соборного заведения книг и икон и прочих приносных пожертвований (публ. И.Л. Ровинской) // Мир старообрядчества. История и современность. Вып. 5. М.: Изд-во МГУ, 1999. С. 377-395.

18. ОРК и Р НБ МГУ. Ф. Южная Вятка. Дневник Калинина. М., 2012.

19. ОРК и Р НБ МГУ. Ф. Южная Вятка. Дневник Богданова. В., 2015.

20. Поздеева И.В. Книжность старообрядческого Верхокамья: истоки, читатели, судьбы (по записям на экземплярах книг Верхокамского собрания НБ МГУ) // Традиционная культура Пермской земли: к 180-летию полевой археографии в Московском университете. Ярославль: Ремдер, 2005. С. 120-141.

21. Поздеева И.В. Назад в будущее - об итогах обсуждения статьи В.В. Керова на конференции и в археографической лаборатории // Традиционная книга и культура позднего русского средневековья. В 2 ч. Ч. 2. Ярославль: Ремдер, 2008. С. 312-321.

22. Поздеева И.В., Дадыкин А.В., Пушков В.П. Московский печатный двор - факт и фактор русской культуры. 1652-1700 годы: исследования и публикации. В 3 кн. Кн. 1. М.: Наука, 2007. 398 с.

23. Поздеева И.В., Ерофеева В.И., Шитова Г.М. Кириллические издания (16 век - 1641 год) Научной библиотеки Московского университета. М.: Изд-во МГУ, 2000. 416 с.

24. Поздеева И.В., Кашкарова И.Д., Леренман М.М. Каталог книг кириллической печати 15-17 вв. в Научной библиотеке Московского университета. М., 1980. 360 с.

25. Поздеева И.В., Пушков В.П., Дадыкин А.В. Московский печатный двор - факт и фактор русской культуры. 1618-1652: от восстановления после гибели в Смутное время до патриарха Никона: исследования и публикации. М.: Наука, 2001. 543 c.

26. Пригарин А.А. "История на полях": записи в книгах липован как историко-этнографический источник // Традиционная книга и культура позднего русского средневековья. В 2 ч. Ч. 2. Ярославль: Ремдер. 2008. С. 149-177.

27. Традиционная книга и культура позднего русского средневековья. В 2 ч. Ярославль: «Ремдер», 2008. 371 с.

28. Филипповское родословие: исторические сочинения старообрядцев-филипповцев Поволжья и Южной Вятки. М.: Археодоксія, 2004. 88 с. 


\section{Исторический журнал: научные исследования № 5 (35) • 2016}

DOI: $10.7256 / 2222-1972.2016 .5 .20012$

\section{References (transliterated):}

1. Arkhiv Mezhkafedral'noi arkheograficheskoi laboratorii (dalee AMAL). F. Verkhokam'e. Dnevnik M.: Lerenman, 1974.

2. AMAL. F. Verkhokam'e. Dnevnik E. Smilyanskoi, 1975.

3. AMAL. F. Yuzhnaya Vyatka. Dnevnik V. Bogdanova, 2011.

4. AMAL. F. Yuzhnaya Vyatka. Dnevnik V. Bogdanova, K. Buinovoi, 2010.

5. Bakhtina O.N. Kirillicheskaya kniga: sovremennye aspekty vospriyatiya i izucheniya // Yazyk, kniga i traditsionnaya kul'tura pozdnego russkogo srednevekov'ya v zhizni svoego vremeni, v nauke, muzeinoi i bibliotechnoi rabote XXI v. M.: Izd-vo MGU, 2011. S. 666-674.

6. Bakhtina O.N., Dutchak E.E. Ot "knigi chitaemoi" k "cheloveku chitayushchemu": iz opyta raboty arkheograficheskoi ekspeditsii Tomskogo universiteta (1986-2006) // Traditsionnaya kniga i kul'tura pozdnego russkogo srednevekov'ya. V 2 ch. Ch. 2. Yaroslavl': Remder, 2008. S. 285-300.

7. Gradoboinova E.V. Rol' kirillicheskikh pechatnykh izdanii v formirovanii mirovozzreniya staroobryadtsev-bespopovtsev // Yazyk, kniga i traditsionnaya kul'tura pozdnego russkogo srednevekov'ya $v$ zhizni svoego vremeni, $v$ nauke, muzeinoi $\mathrm{i}$ bibliotechnoi rabote XXI v. M.: Izd-vo MGU, 2011. S. 610-624.

8. Dutchak E.E. Iz "Vavilona" v "Belovod'e": adaptatsionnye vozmozhnosti taezhnykh obshchin staroverov-strannikov (vtoraya polovina XIX v. - nachalo XXI v.). Tomsk: Izd-vo Tom. un-ta, 2007. $414 \mathrm{~S}$.

9. Dutchak E.E. Polevaya arkheografiya vchera, segodnya i zavtra: razmyshleniya o novykh publikatsiyakh Moskovskogo universiteta // Vestnik Tomskogo gosudarstvennogo universiteta. 2015. № 396. S. 85-90.

10. Dutchak E.E. Staroobryadcheskaya kniga: "bolevye tochki" nauchnogo opoznaniya pozdnei kirillicheskoi rukopisi // Yazyk, kniga i traditsionnaya kul'tura pozdnego russkogo srednevekov'ya v zhizni svoego vremeni, v nauke, muzeinoi i bibliotechnoi rabote XXI v. M.: MGU, 2011. S. 674-689.

11. Zernova A.S. Knigi kirillovskoi pechati, izdannye v Moskve v XVI-XVII vv. M.: GBL, 1958. 152 s.

12. Kerov V.V. Ob arkheografii: klassicheskoi i sotsial'noi // Traditsionnaya kniga i kul'tura pozdnego russkogo srednevekov'ya. V 2 ch. Ch. 2. Yaroslavl': Remder. 2008. S. 300-312.

13. Kirillicheskie izdaniya XVI-XVII vv. v khranilishchakh Permskoi oblasti. Perm', 2003. 488 s.

14. Kirillicheskie izdaniya Rostovo-Yaroslavskoi zemli (1493-1652 gg). Yaroslavl' - Rostov, 2004. $630 \mathrm{~s}$.

15. Materialy k istorii staroobryadchestva Verkhokam'ya: po itogam kompleksnykh arkheograficheskikh ekspeditsii istoricheskogo fakul'teta MGU imeni M.V. Lomonosova: sbornik dokumentov, M.: MAKS Press, 2013. 276 s.

16. Materialy $\mathrm{k}$ istorii staroobryadchestva Yuzhnoi Vyatki (po itogam kompleksnykh arkheograficheskikh ekspeditsii MGU imeni M.V. Lomonosova). M.: MAKS Press, 2012. 306 s.

17. Opisanie sobornogo zavedeniya knig i ikon i prochikh prinosnykh pozhertvovanii (publ. I.L. Rovinskoi) // Mir staroobryadchestva. Istoriya i sovremennost'. Vyp. 5. M.: Izd-vo MGU, 1999. S. 377-395.

18. ORK i R NB MGU. F. Yuzhnaya Vyatka. Dnevnik Kalinina. M., 2012.

19. ORK i R NB MGU. F. Yuzhnaya Vyatka. Dnevnik Bogdanova. V., 2015.

20. Pozdeeva I.V. Knizhnost' staroobryadcheskogo Verkhokam'ya: istoki, chitateli, sud'by (po zapisyam na ekzemplyarakh knig Verkhokamskogo sobraniya NB MGU) // Traditsionnaya kul'tura Permskoi zemli: k 180-letiyu polevoi arkheografii v Moskovskom universitete. Yaroslavl': Remder, 2005. S. 120-141.

21. Pozdeeva I.V. Nazad v budushchee - ob itogakh obsuzhdeniya stat'i V.V. Kerova na konferentsii i varkheograficheskoi laboratorii // Traditsionnaya kniga i kul'tura pozdnego russkogo srednevekov'ya. V 2 ch. Ch. 2. Yaroslavl': Remder, 2008. S. 312-321.

22. Pozdeeva I.V., Dadykin A.V., Pushkov V.P. Moskovskii pechatnyi dvor - fakt i faktor russkoi kul'tury. 1652-1700 gody: issledovaniya i publikatsii. V 3 kn. Kn. 1. M.: Nauka, 2007. 398 s.

23. Pozdeeva I.V., Erofeeva V.I., Shitova G.M. Kirillicheskie izdaniya (16 vek - 1641 god) Nauchnoi biblioteki Moskovskogo universiteta. M.: Izd-vo MGU, 2000. 416 s.

24. Pozdeeva I.V., Kashkarova I.D., Lerenman M.M. Katalog knig kirillicheskoi pechati 15-17 vv. v Nauchnoi biblioteke Moskovskogo universiteta. M., 1980. $360 \mathrm{~s}$.

25. Pozdeeva I.V., Pushkov V.P., Dadykin A.V. Moskovskii pechatnyi dvor - fakt i faktor russkoi kul'tury. 1618-1652: ot vosstanovleniya posle gibeli v Smutnoe vremya do patriarkha Nikona: issledovaniya i publikatsii. M.: Nauka, 2001.543 s.

26. Prigarin A.A. "Istoriya na polyakh": zapisi v knigakh lipovan kak istoriko-etnograficheskii istochnik // Traditsionnaya kniga i kul'tura pozdnego russkogo srednevekov'ya. V 2 ch. Ch. 2. Yaroslavl': Remder. 2008. S. 149-177.

27. Traditsionnaya kniga i kul'tura pozdnego russkogo srednevekov'ya. V 2 ch. Yaroslavl': «Remder», 2008. $371 \mathrm{~s}$.

28. Filippovskoe rodoslovie: istoricheskie sochineniya staroobryadtsev-filippovtsev Povolzh'ya i Yuzhnoi Vyatki. M.: Arkheodoksiya, 2004. $88 \mathrm{~s}$. 